\title{
MERINTIS SOCIAL ENTREPRENEURSHIP DENGAN MENGEMBANGKAN KARAKTER PEDULI LINGKUNGAN PADA REMAJA CEPOKOJAJAR
}

\author{
Astuti Wijayanti $^{1 *}$, Tias Ernawati ${ }^{1}$, Laily Rochmawati Listiyani ${ }^{1}$, Rini Nurhayati $^{1}$ \\ ${ }^{1}$ Program Studi Pendidikan Ilmu Pengetahuan Alam, Fakultas Keguruan dan Ilmu Pendidikan, Universitas \\ Sarjanawiyata Tamansiswa, Yogyakarta, Indonesia \\ *Penulis Korespondensi: astuti.wijayanti@ustjogja.ac.id
}

\begin{abstract}
Abstrak
Pertanian merupakan bidang yang sangat strategis untuk dikembangkan terutama oleh remaja agar memiliki kepedulian dengan lingkungan sekaligus juga membangun jiwa social entrepreneur. Kegiatan pengabdian kepada masyarakat ini memiliki tujuan untuk memotivasi remaja Cepokojajar Sitimulyo Piyungan Bantul untuk meningkatkan rasa kepedulian terhadap lingkungan melalui wirausaha di bidang pertanian. Kegiatan ini dilaksanakan dengan metode diskusi, tanya jawab dan praktik yang dikemas dalam kegiatan sosialisasi serta simulasi. Materi yang diangkat yaitu tentang ketahanan pangan, perawatan tanaman, pembuatan nutrisi tumbuh, dan pupuk kompos dalam biopori, dan social entrepreneurship. Peserta nampak antusias dan kegiatan terlaksana dengan baik dan lancar. Hasil kegiatan ini antara lain: 1) remaja mampu mempraktikkan perawatan tanaman, pembuatan nutrisi tumbuh, pembuatan pupuk kompos dalam biopori; 2) remaja termotivasi untuk memulai peduli terhadap lingkungan dengan mengelola sampah rumah tangga/sampah organik dan menanam tanaman; dan 3) remaja termotivasi untuk memulai merintis usaha. Karangtaruna hendaknya dapat mengikuti pelatihan secara berkala sehingga potensi mereka dapat semakin berkembang dan bermanfaat bagi sekitarnya.
\end{abstract}

Kata Kunci: Peduli Lingkungan, Social Entrepreneurship.

\begin{abstract}
Agriculture is a very strategic field to be developed specially by adolescents so that they have concern for the environment while also building a social entrepreneur spirit. This community service activity aims to motivate young people in Cepokojajar Sitimulyo Piyungan Bantul to increase their sense of care for the environment through entrepreneurship in agriculture. This activity is carried out with the method of discussion, question and answer and practice that is packaged in socialization and simulation activities. The material raised is about food security, plant care, manufacturing of growing nutrients, and compost fertilizer in bio pores, and social entrepreneurship. The participants seemed enthusiastic and the activities carried out well and smoothly. The results of these activities include: 1) adolescents are able to practice plant care, manufacture growing nutrients, compost fertilizer in bio pores; 2) youth are motivated to start caring for the environment by managing household / organic waste and growing plants, and 3) teenagers are motivated to start starting a business. Karangtaruna should be able to take part in regular training so that their potential can further develop and benefit the surrounding area.
\end{abstract}

Keywords: Care For The Environment, Social Entrepreneurship.

\section{PENDAhuluan}

Social entrepeneurship merupakan salah satu istilah dalam kewirausahaan. Seseorang mengamati permasalahan sosial kemudian bertindak mengambil keputusan dalam menyelesaikan permasalahan melalui entrepreneurship untuk melakukan perubahan sosial terutama dalam bidang kesejahteraan, kesehatan dan pendidikan. Praktik social entrepreneurship di Indonesia semakin pesat dan bergerak dalam berbagai bidang seperti pendidikan, kesehatan, pemberdayaan perempuan, lingkungan, dan pertanian (Maulinda, 2019). Berkembangnya social entrepreneurship diperlukan untuk mengatasi masyarakat yang mengalami kemiskinan dan mengatasi angka pengangguran yang semakin tinggi.

Berbagai faktor yang mempengaruhi social entrepreneurship meliputi berbagai kondisi seperti kondisi sosial, ekonomi, persaingan, permintaan, perkembangan teknologi dan peluang usaha. Langkah yang perlu dilakukan adalah 1) identifikasi permasalahan social, 2) identifikasi peluang usaha, dan 3) melakukan perubahan berupa aksi. Cukup luasnya lahan yang dimiliki warga dan manakala hasil bumi yang dihasilkan tersebut dapat diolah menjadi barang yang memiliki nilai jual yang cukup tinggi, maka dapat 
meningkatkan perekonomian warga (Fahmi \& Shinta, 2019). Melalui kegiatan social entrepreneurship ini diharapkan membuka lapangan pekerjaan, membuka peluang usaha, melakukan inovasi dalam usaha sesuai perkembangan zaman, dan pelestarian kebudayaan. Hal tersebut didukung oleh pendapat Saputri, dkk (2016) bahwa terdapat peluang pada ketahanan pangan di suatu wilayah yang dapat diukur dari ketersediaan pangan, daya beli, dan tingkat konsumsi penduduk. Sebagai contoh yang telah diterapkan oleh Kiryanto, dkk (2018) bahwa produksi pupuk kompos dapat menambah peluang usaha bagi anggota kelompok tani ternak KKT 'Berkah Sari', baik dengan pemasaran online maupun offline dapat menambah pendapatan anggota. Selain itu, Sulistyawati, dkk (2019) juga menambahkan bahwa masyarakat dapat membuat pupuk organik yang berupa pupuk cair dan kompos dari sampah lingkungan sekitar untuk memupuk tanaman baik tradisional maupun hidroponik sehingga masyarakat tidak perlu membeli pupuk dan menambah efisiensi pada rumah tangga tersebut

Hasil observasi pada bulan Juni, Cepokojajar Sitimulyo Piyungan Bantul merupakan salah satu dusun yang luas dan masih asri. Lingkungannya terdiri dari persawahan, kolam ikan, lahan pembuatan batu bata. Setiap rumah penduduk sebagian besar masih sangat luas dan memungkinkan untuk bercocok tanam. Namun, dalam kesehariannya yang secara rutin ke sawah dan melakukan cetak batu bata adalah penduduk dengan usia 45-70 tahun. Diperoleh data aktivitas remaja di Cepokojajar dengan rentang usia 12-18 tahun berada pada usia sekolah menengah cenderung banyak menghabiskan waktunya di sekolah dan bergaul dengan teman. Mereka jarang sekali membantu aktivitas orang tua yang mayoritas bermata pencaharian pedagang dan petani. Beberapa rumah yang lahannya tergolong luas, juga nampak kosong belum terisi dengan tanaman tanaman. Selain itu, beberapa penduduk mengalami kurang stabilnya perekonomian keluarga. Hal tersebut mengindikasikan bahwa pemanfaatan lahan oleh masyarakat belum optimal dan kesadaran remaja terhadap lingkungan masih kurang sehingga perlu ditumbuhkan dan juga perlu dimotivasi untuk memulai kegiatan yang positif dalam kesehariannya seperti memulai social entrepreneurship. Hal tersebut dapat disebabkan karena masyarakat tidak memiliki keterampilan, pengalaman, pengetahuan, dan motivasi dalam menggali potensi daerah (Suryani, dkk, 2019). Oleh karena itu, kegiatan pengabdian kepada masyarakat ini dilakukan pada dusun tersebut untuk dapat memanfaatkan potensi di dusun cepokojajar secara optimal.

Berdasarkan analisis situasi dan kebutuhan yang telah diuraikan, tujuan kegiatan pengabdian masyarakat ini adalah: untuk membantu remaja Cepokojajar dalam kegiatan merintis social enterpreneurship dengan mengembangkan karakter peduli lingkungan. Hal tersebut dapat terealisasi melalui berbagai kegiatan positif untuk mengembangkan ketrampilan remaja dalam memanfaatkan potensi lingkungan dan sumber daya alam terutama pada bidang pertanian. Melalui kegiatan pengabdian ini remaja terlibat dalam kegiatan praktik, menganalisis, dan merencanakan peluang wirausaha di bidang pertanian, antara lain dengan memproduksi dan mengolah tanaman bibit unggul dengan nutrisi yang baik. Selain itu, kegiatan ini juga menanamkan karakter peduli lingkungan pada remaja Cepokojajar sehingga remaja dapat mulai peduli terhadap lingkungan tempat tinggalnya terutama memanfaatkan lahan di rumah dengan menanan tanaman pangan. Melalui social entrepreneurship yang inovatif pada remaja dapat memberikan peluang usaha baru bagi masyarakat.

\section{BAHAN DAN METODE}

Pengabdian masyarakat ini dilaksanakan di Cepokojajar Sitimulyo Piyungan Bantul. Kegiatan ini dilaksanakan pada Juli 2019. Peserta kegiatan ini sejumlah 15 remaja RT 03 RW 23 Cepokojajar. Persiapan yang dilakukan oleh tim pengabdian yaitu; 1) koordinasi dengan RT dan remaja Cepokojajar; 2) koordinasi dengan WALHI untuk pengadaan bibit, peralatan dan praktisi, 3) pembuatan buku saku materi sosialisasi, 4) pembuatan presensi, 5) pembuatan lembar evaluasi, serta 6) mempersiapkan simulasi dan praktik pembuatan biopori. Kegiatan pengabdian masyarakat ini dilaksanakan dengan cara membagi peserta dalam kelompok-kelompok kecil untuk mempraktikan bagianbagian materi sosialisasi secara langsung, berdiskusi dan bertanya jawab. Tim pengabdian memberikan 1) sosialisasi terkait dengan ketahanan pangan dan lingkungan, 2) sosialisasi social entrepreneurship dan 3) pelatihan perawatan tanaman, pembuatan nutrisi tumbuh, dan pembuatan pupuk kompos dalam biopori. Pengumpulan data pada pengabdian ini dengan menggunakan teknik observasi dan dokumentasi yang akan dijabarkan secara deskriptif. Respon remaja terhadap kegiatan pengabdian ini dapat dilihat dari lembar evaluasi yang telah diisi oleh peserta.

\section{HASIL DAN PEMBAHASAN}

Kegiatan pengabdian masyarakat dilaksanakan oleh tim pengabdian Pendidikan IPA FKIP UST, den pembagian tugas seperti pada tabel berikut.

Tabel 1. Pembagian Tugas Tim Pengabdian.

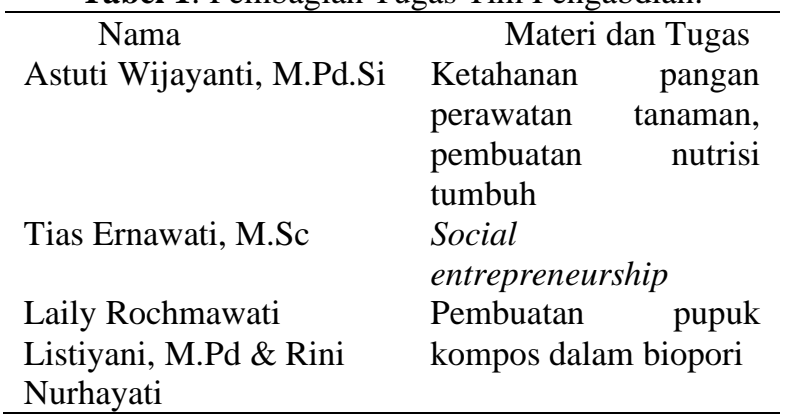




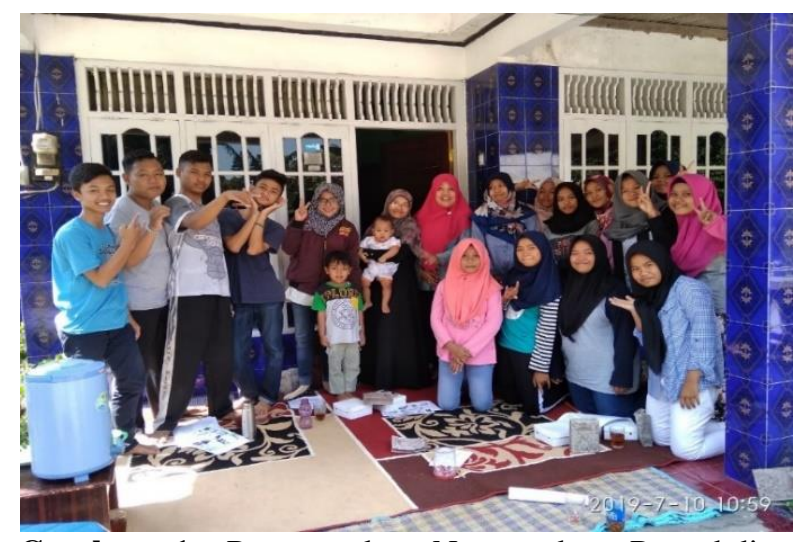

Gambar 1. Peserta dan Narasumber Pengabdian Masyarakat.

Kegiatan ini bekerjasama dengan Wahana Lingkungan Hidup (WALHI) Yogyakarta dalam hal pengadaan benih/bibit tanaman, peminjaman peralatan dan perwakilan praktisi untuk pembuatan biopori. Pada kegiatan pengabdian ini peserta dilatih untuk membuat biopori pada lahan yang tersedia di rumah dengan menggunakan alat bor biopori dan paralon ukuran besar. Peserta diberi pengetahuan tentang manfaat biopori bagi lingkungan. Peserta juga diarahkan untuk dapat memisahkan sampah rumah tangga ke dalam kelompok sampah organik dan anorganik. Sampah organik dapat dimanfaatkan untuk mengisi paralon biopori secara rutin. Jika waktu telah cukup maka sampah organik dalam biopori dapat dipakai menjadi pupuk kompos. Salah satu cara perawatan tanaman dapat dilakukan dengan memberikan pupuk kompos ke dalam media tanam sehingga tanaman dapat tumbuh subur.

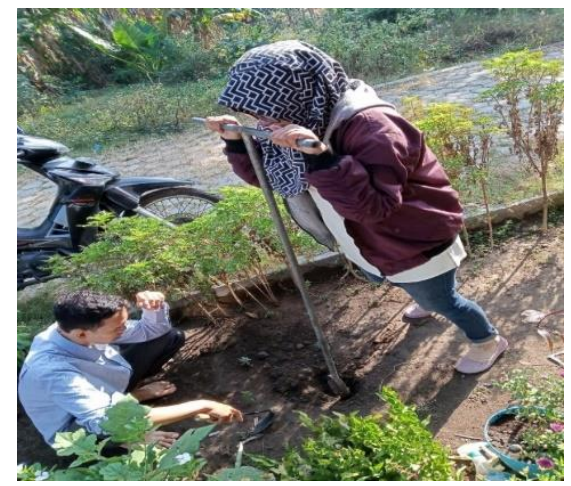

Gambar 2. Pembuatan lubang biopori dan pemberian paralon pada lubang yang dibuat.

Sampah organik lain seperti sisa potongan sayuran dapat ditumbuhkan kembali. Peserta kegiatan diminta untuk mempraktekkan cara-cara menanam sisa potongan sayuran serta cara membuat nutrisi tanaman dengan memanfaatkan bahan-bahan sederhana dari sampah organik. Peserta juga diminta mempraktikan cara menanam benih-benih unggul yang baik untuk menghasilkan produk yang terbaik.

Di akhir kegiatan, peserta diberi wawasan mengenai teknologi perkembangbiakan tanaman dengan cara hidroponik. Peserta menerima pengetahuan tentang keunggulan hidroponik dan manfaat berwirausaha dengan hidroponik. Peserta mendapat contoh-contoh mengenai social entrepreneurship. Antusias peserta dapat dilihat dari munculnya pertanyaan-pertanyaan saat kegiatan sosialisasi.

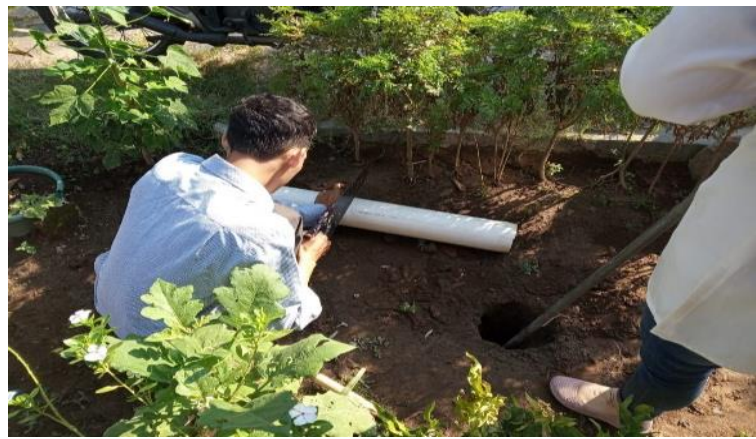

Gambar 3. Membuat paralon bahan biopori.

Kesadaran remaja untuk peduli terhadap lingkungan yang dapat ditumbuhkan, dapat mewujudkan perilaku menjaga lingkungan dengan baik (Helmi, dkk., 2018). Melalui kegiatan peduli lingkungan tersebut, remaja juga dibekalkan ilmu tentang social entrepreneurship yang dapat dihubungkan dengan tanaman pangan baik pada pertanian tradisional maupun modern. Peranan social entrepreneur dalam bidang ekonomi antara lain: 1) Menciptakan kesempatan kerja; 2) Melakukan inovasi dan kreasi baru terhadap produksi barang atau jasa yang dibutuhkan masyarakat; 3) Menjadi modal sosial (jaringan kepercayaan dan kerjasama); dan 4) Peningkatan kesetaraan dan pemerataan kesejahteraan masyarakat. Peserta dikenalkan juga dengan beberapa pemuda inspiratif yang telah sukses bergerak di bidang pertanian dengan hidroponik dan sebagainya sehingga dapat memotivasi remaja dalam ber-enterpreneur di usia muda.

Kegiatan ini melibatkan seluruh peserta untuk praktik membuat beberapa produk pertanian yang dapat digunakan dalam kegiatan wirausaha atau kegiatan melatih social enterpreneurship. Produk yang dihasilkan diantaranya: 1) benih biji tanaman unggul, 2) tanaman pangan (kentang, pepaya, tomat, cabai); 3) kompos, dan 4) pupuk cair organik, nutrisi bagi tanaman dan pestisida alami. Pada kegiatan praktik, remaja nampak sangat antusias dalam melakukan proses pembibitan, penanaman tanaman pangan, pembuatan media tanam, pembuatan nutrisi bagi tanaman dan pupuk kompos. Kegiatan ini juga dilanjutkan dengan mencontohkan analisis dan rencana wirausaha dari hasil pertanian salah satunya yaitu pepaya dapat dijual bagian daun, buah maupun bentuk olahan lainnya. Satu buah pepaya menghasilkan banyak sekali biji yang dapat ditumbuhkan menjadi bibit unggul dan bibit unggul tersebut dapat juga dijual. Jika satu biji pepaya dapat tumbuh subur, panen dapat menghasilkan puluhan buah pepaya dalam satu tahun yang dapat diperjualbelikan dan memenuhi kebutuhan pangan masyarakat. Hasil tersebut dapat dimanfaatkan atau diolah agar menambah nilai ekonomi. 


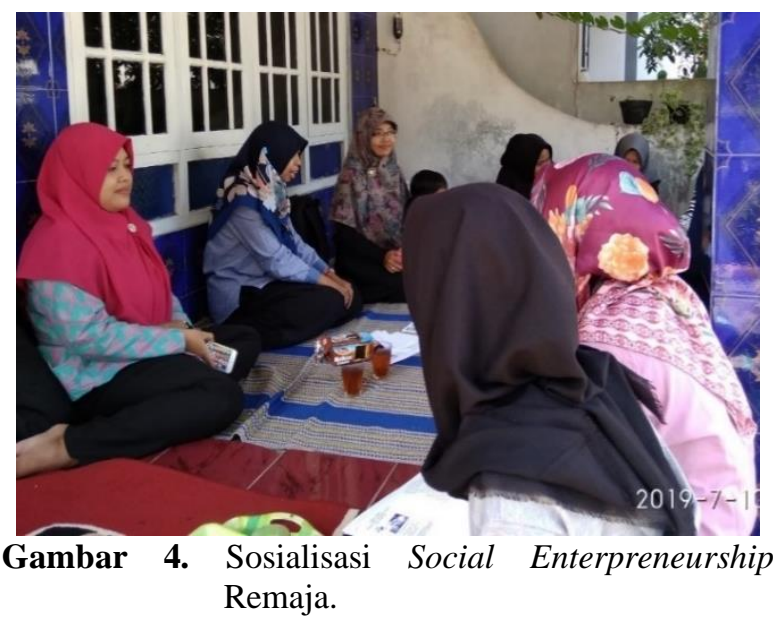

Beberapa langkah yang dapat dilakukan untuk merintis social entrepeneurship sebagai berikut:

1. Mengenali dan belajar dengan orang-orang yang telah sukses di bidang pertanian, kemudian menirukan langkah yang telah dilakukan/nyantrik.

2. Niteni atau melakukan pengamatan dan memilih bibit unggul tanaman.

3. Mempelajari cara, tips dan trik dalam bertanam dan berwirausaha baik melalui media cetak maupun media elektronik dan jaringan.

4. Berlatih melakukan perencanaan tentang merintis social entrepreneurship dan melakukan analisis kebutuhan lingkungan masyarakat serta sasaran pemasaran hasil usaha pertanian.

5. Konsisten dalam pembibitan tanaman pangan. Luaran produk dapat langsung dijual atau diolah menjadi makanan olahan berbahan dasar tanaman pangan tersebut.

6. Konsisten mengumpulkan sampah organik dan memanfaatkannya sebagai pupuk cair organik, kompos, nutrisi tanaman dan pestisida.

7. Memanfaatkan teknologi terkini seperti hidroponik agar dapat bertanam meskipun pada lahan sempit.

8. Melakukan packaging atau pengemasan yang menarik pada produk olahan.

9. Memberikan label keterangan pada produk yang akan dipasarkan.

10. Menentukan harga jual melalui perhitungan modal dan laba yang diinginkan.

11. Teknik pemasaran dapat dilakukan secara sederhana melalui penitipan di pusat perbelanjaan, pameran, dan ditawarkan melalui pemanfaatan media sosial (Facebook, Instagram, dan Whatshapp)

Hasil dari pelaksanaan kegiatan ini diperoleh data secara kuantitatif bahwa peserta kegiatan dapat membuat 7 paket tanaman pangan, baik cabai, tomat, pepaya dan kentang, dan 7 botol pupuk cair dan nutrisi bagi tanaman, hasil lain peserta dapat membuat lubang resapan biopori. Mereka memberikan kesan pada lembar evaluasi bahwa kegiatan ini sangat bermanfaat dan aplikatif. Kegiatan ini telah memberikan dampak yang positif bagi mereka. Mereka bertekad akan memulai memisahkan sampah organik dan anorganik, menanan tanaman pangan sendiri dan membuat nutrisi serta pupuk kompos sehingga dapat merawat lingkungan dengan mudah, murah dan bermanfaat. Mereka juga merasa termotivasi untuk dapat berwirausaha sejak remaja, sehingga dapat mengisi waktu luangnya dengan kegiatan positif.

\section{KESIMPULAN}

Remaja merupakan bagian dari masyarakat produktif yang memiliki kemampuan untuk berpartisipasi dalam menggerakkan seluruh masyarakat untuk bekerja sama mengatasi berbagai permasalahan yang dihadapi. Kesadaran remaja terhadap pentingnya kewirausahaan sosial dapat merintis kemandirian finansial, sosial, dan pemanfaatan lingkungan yang bertanggung jawab. Menumbuhkan kepedulian lingkungan pada remaja hendaknya dapat dilakukan secara berkelanjutan, baik dilakukan dari karang taruna, maupun bekerjasama dengan perguruan tinggi dan instansi yang lainnya.

Potensi remaja hendanya dapat disalurkan dan dikembangkan melalui berbagai kegiatan positif agar menjadi potensi yang dapat membangun masyarakat di Cepokojajar. Kesadaran peduli lingkungan dan motivasi pada diri remaja perlu ditumbuhkan melalui kegiatan pengolahan sumber daya alam khusunya pada bidang pertanian. Kegiatan pengabdian ini berhasil mengajak remaja dalam melakukan pembibitan tanaman, pembuatan pupuk dan nutrisi pada tanaman, serta praktik pembuatan lubang resapan biopori. Disamping itu, social entrepreneurship dapat dibangun sejak remaja melalui pemahaman dan latihan wirausaha pengolahan hasil pertanian sehingga remaja memiliki target dan rencana jangka panjang untuk membuka peluang usaha mandiri.

\section{UCAPAN TERIMA KASIH}

Ucapan terima kasih terutama ditujukan kepada UST dan LP3M yang telah memberikan bantuan dalam kegiatan pengabdian ini. WALHI yang telah membantu peralatan dan bibit dan juga kami sampaikan ucapan terima kasih kepada pihak-pihak yang membantu pelaksanaan penelitian terutama karangtaruna dusun Cepokojajar Piyungan.

\section{DAFTAR PUSTAKA}

Fahmi, S., \& Shinta, F. S. (2019). Pemberdayaan ekonomi masyarakat melalui pengolahan hasil bumi lokal untuk meningkatkan minat berwirausaha, 3(1), 5-8.

Helmi, H., Nengsih, Y. K., \& Suganda, V. A. (2018). Peningkatan kepedulian lingkungan melalui pembinaan penerapan sistem 3R (reduce, reuse, recycle). JPPM (Jurnal Pendidikan Dan Pemberdayaan Masyarakat), 5(1), 1-8. http://doi.org/10.21831/jppm.v5i1.16861

Kiryanto, K., Chrismianto, D., \& Puskhah, E. (2018). Upaya Pemanfaatan Sumberdaya Pedesaan Berbasis Pengembangan Kelompok Peternak melalui Pengolahan Limbah Kotoran Menjadi Produk Energi Terbarukan dan Produk yang Bermanfaat untuk Kesejahteraan Masyarakat Desa Branjang Kabupaten Semarang. E-Dimas: 
Jurnal Pengabdian Kepada Masyarakat, 9(2), 185. http://doi.org/10.26877/e-dimas.v9i2.1810

Maulinda, K. (2019). Proses Pengembangan Social Enterprise Agriculture: Studi Biografi Pada Agradaya. Jurnal Studi Pemuda, 7(2), 133. http://doi.org/10.22146/studipemudaugm.40114

Saputri, R., Lestari, L. A., \& Susilo, J. (2016). Pola konsumsi pangan dan tingkat ketahanan pangan rumah tangga di Kabupaten Kampar Provinsi Riau. Jurnal Gizi Klinik Indonesia, 12(3).

Sulistyawati, Maulana, M., Tentama, F., Mulasari, S. A., \& Sukesi, T. W. (2019). Pendampingan pembuatan sistem hidroponik dan pengolahan sampah organik. Jurnal Pengabdian Dan Pemberdayaan Masyarakat, 3(1), 77-82.

Suryani, D., Kurniawan, D., Melizan, D. S., \& Putra, G. (2019). Pemberdayaan masyarakat Dusun Jaten , Mrico dan Bruno 1 untuk meningkatkan ketahanan pangan dengan pemanfaatan potensi lokal. Jurnal Pemberdayaan: Publikasi Hasil Pengabdian Kepada Masyarakat, 3(1), 39-44. 